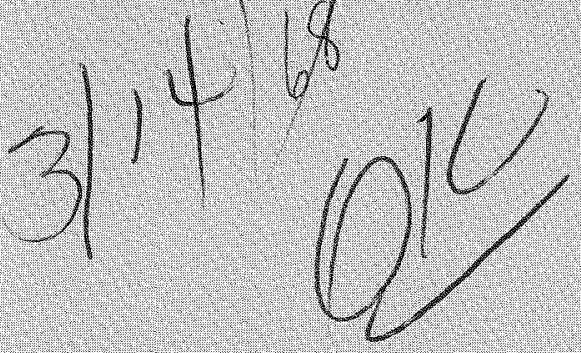

\title{
CHEMICAL MILLING OF BERYLLIUM
}
R. C. Anderson
R. L. Ludwig

\section{UNION CAREIDE CORPORATION}

\section{NUOLEAR DIVISION}

OAK RIECE Y-12 PLANT.

operated for the ATOMIC ENERGY COMMISSION under U. S. GOVERNMENT Contract W.7405 eng 26

UNION CARBDE
OAK RIDGE Y.12 PLANT

P. O. BoX Y

OAK RIDGE, TENNESSEE 37830 


\section{DISCLAIMER}

This report was prepared as an account of work sponsored by an agency of the United States Government. Neither the United States Government nor any agency Thereof, nor any of their employees, makes any warranty, express or implied, or assumes any legal liability or responsibility for the accuracy, completeness, or usefulness of any information, apparatus, product, or process disclosed, or represents that its use would not infringe privately owned rights. Reference herein to any specific commercial product, process, or service by trade name, trademark, manufacturer, or otherwise does not necessarily constitute or imply its endorsement, recommendation, or favoring by the United States Government or any agency thereof. The views and opinions of authors expressed herein do not necessarily state or reflect those of the United States Government or any agency thereof. 


\section{DISCLAIMER}

Portions of this document may be illegible in electronic image products. Images are produced from the best available original document. 
Printed in the Unifed States of America. Avalable from Clearinghouse for Federal

Scientific and Technical Information, National Bureau of Siandards.

U.S. Department of Commerce, Springfield, Virginia 22151

Price. Printed Copy $\$ 3.00$ Microfiche $\$ 0.65$

\section{LEGAL NOTICE}

This report was prepared as an account of Government sponsored work. Neither the Untted States, nor the Commission, nor any person acting on behalf of the Commission

A Makes any warranty or representation, expressed or implied, with respect to the accuracy, completeness, or usefulness of the information contaned in this report, or that the use of any information, apparatus, method, or process disclosed in this report may not infringe privately owned rights, or

B. Assumes any liabilities with respect to the use of, or for damages resulting from the use of any information, apparatus, method, or process disclosed in this report.

As used in the above, "person acting on behalf of the Commission" includes any employee or contractor of the Commission, or employee of such contractor, to the extent that such employee or contractor of the Commission, or employee of such contractor prepares, disseminates, or provides access to, any information pursuant to his employment or contract with the Commission, or his employment with such contractor. 


\title{
UNION CARBIDE CORPORATION Nuclear Division
}

$$
Y=12 \text { PLANT }
$$

Contract W-7405-eng-26

With the US Atomic Energy Commission

\section{CHEMICAL MILLING OF BERYLLIUM}

\author{
R. C. Anderson \\ R. L. Ludwig
}

\section{LEGAL NOTICE}

This report was prepared as an account of Government sponsored work. Neither the United States, nor the Commission, nor any person acting on behalf of the Commission:

A. Makes any warranty or representation, expressed or implied, with respect to the accuracy, completeness, or usefulness of the information contained in this report, or that the use of any information, apparatus, method, or process disclosed in this report may not infringe privately owned rights; or

B. Assumes any liabilities with respect to the use of, or for damages resulting from the use of any information, apparatus, method, or proeess disclosed in this report.

As used in the above, "person acting on behalf of the Commission" inciudes any employee or contractor of the Commission, or employee of such contractor, to the extent that such employee or contractor of the Commission, or employee of such contractor prepares, disseminates, or provides access to, any information pursuant to his employment or contract with the Commission, or his employment with such contractor.

Oak Ridge, Tennessee 
Document $Y-1612$

Engineering and Equipment

TID -4500

Distribution:

Alvey, H. E.

McLendon, J.D.

Anderson, R. C. (8)

Meeks, E. J. (AFSC)

Bailey, E. W.

Mitchel, G. W.

Ballenger, H. F.

Phillips, L. R.

Bernander, N. K.

Smith, R. D.

Burkhart, L. E.

Stoner, H. H.

Cromer, S. J. (ORGDP)

Tilson, F. V.

Ellingson, R. D.

Vanstrum, $P$. R.

Evans, G. W.

Warner, J. F.

Fortenbery, M. J.

Waters, J. L.

Gritzner, V. B.

Wesley, R. L.

Harwell, W. L. (ORGDP) (5)

Whitson, W. K.

Hemphill, L. F.

Winkel, R. A. (Paducah)

Huber, A. P. (ORGDP)

Wood, D. C.

Jackson, V. C.

Jordan, R. G. (ORGDP)

Yaggi, $\dot{W} . J$.

Zurcher, $E$.

Keller, C. A. (AEC-ORO)

$Y-12$ Central Files (5)

Kite, H. T.

$Y-12$ Central Files $(Y-12 R C)$

Library of Congress (4)

Ludwig, R. L. (8)

In addition, this report is distributed in accordance with the category, Engineering and Equipment, as given in the "USAEC Standard Distribution Lists for Unclassified Scientific and Technical Reports", TID-4500. 


\section{ABSTRACT}

Chemical milling of beryllium ingot sheet was investigated as an inexpensive, alternate method for producing the radiative fins for the SNAP-27 Radioisotope Thermoelectric Generator. Fin specimens were submerged in a sulfuric acid bath maintained at a constant temperature, then slowly rotated while being withdrawn from the bath at a constant rate of speed. This procedure should have produced uniformily tapered fins within a reasonable length of time. However, there were variations in the taper due to the nonuniform thickness of the hot-rolled beryllium sheet and a preferential attack at the rolling defects in the beryllium sheet. 
CONTENTS

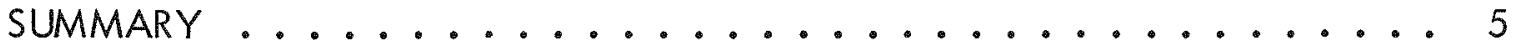

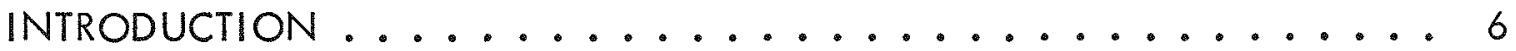

STEPS IN THE CHEMICAL MILLING STUDY ............. 7

Specimen Preparation ................... 7

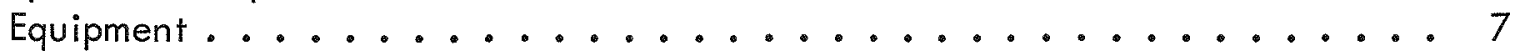

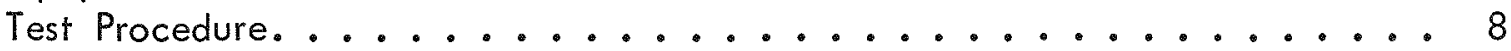

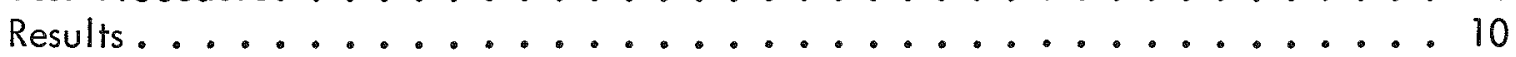

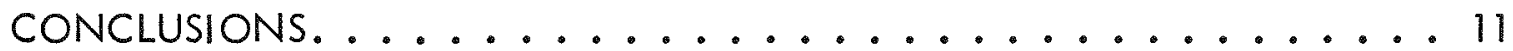


SUMMARY

Chemical milling of beryllium ingot sheet was investigated as an inexpensive, alternate method for machining the radiative fins for the SNAP-27 Radioisotope Thermoelectric Generator.

Fin specimens were submerged in a sulfuric acid bath maintained at a constant temperature, then slowly rotated while being withdrawn from the bath at a constant rate of speed. This procedure was designed to produce tapered fins. The following points were noted:

1. The rate at which the specimen was withdrawn from the bath had to be increased to 0.112 inch per minute to prevent excess removal of stock.

2. The bath temperature was very critical and had to be maintained at $27^{\circ} \mathrm{C}$ to obtain the correct taper.

3. A fresh solution was required for each specimen to control the dissolution rate and produce the desired taper of the specimen.

4. To maintain a uniform taper during the chemical milling operation, a uniform thickness of the starting sheet was required.

The results demonstrated that the taper of the beryllium fins could be chemically milled in a sulfuric acid bath within a reasonable length of time, but a variation in the taper existed over the length of the specimen due to the nonuniform thickness of the hot-rolled beryllium ingot sheet. 


\section{INTRODUCTION}

Chemical milling is a process by which metal is removed by controlled dissolution into a chemical bath. The bath, in essence, is a highly refined pickling solution. Careful attention must be given to the rate of metal removed and to the type of surface left after processing.

Chemical milling is particularly adaptable to the fabrication of various shapes from beryllium sheet, where other types of machining would be either difficult or expensive. Consequently, chemical-milling studies were proposed for beryllium ingot sheet to demonstrate the feasibility and economy of this technique for machining tapered radiative fins for the Radioisotope Thermoelectric Generator designated as SNAP-27.

Each of the twelve radiative fins for the generator was to be 18 inches long, 7 inches wide, and tapered, in the 7-inch direction, from $0.107 \pm 0.003$ inch at the base to $0.027 \pm 0.003$ inch at the tip (a 0.080 -inch taper) with a tolerance specification of \pm 5 percent on all dimensions along the taper. 
STEPS IN THE CHEMICAL MILLING STUDY

\section{SPECIMEN PREPARATION}

The wrought ingot beryllium sheet from which the specimens were machined was somewhat warped and had a thickness that varied between 0.273 and 0.288 inch. Six specimens $\left(81 / 2^{\prime \prime} \mathrm{L} \times 31 / 2^{\prime \prime} \mathrm{W} \times 0.273\right.$ to $\left.0.288^{\prime \prime} \mathrm{T}\right)$ were machined from the ingot beryllium sheet. Prior to chemical milling, surfaces of the plate were prepared by pickling $\left(50 \% \mathrm{H}_{3} \mathrm{PO}_{4}\right)$, vapor degreasing, and immersing in an alkaline bath.

\section{EQUIPMENT}

Development equipment for chemical milling beryllium is shown schematically in Figure 1. The assembled equipment consisted of a tank to contain the chemical milling solution, an agitator to stir the solution, heating units and a cooling coil to maintain the temperature of the bath between very close limits, a motor to rotate the specimen to prevent cavitation of the surfaces, and a variable-speed mechanism to lift the specimen from the solution at a constant rate. A photograph of the assembly with the fin specimen in the withdrawn position is presented in Figure 2.

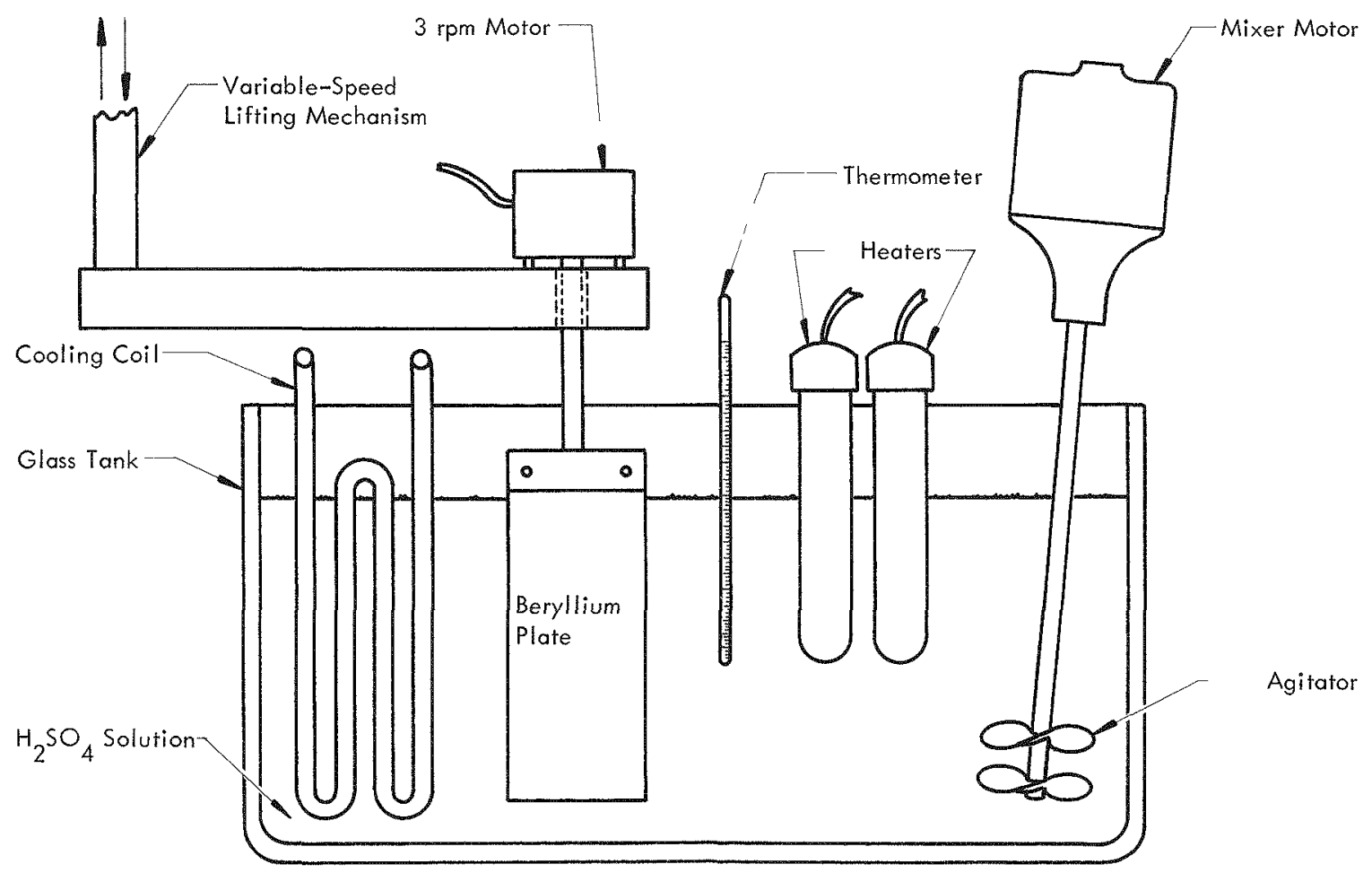

Figure 1. DEVELOPMENT EQUIPMENT FOR THE STUDY OF CHEMICAL MILLING. 


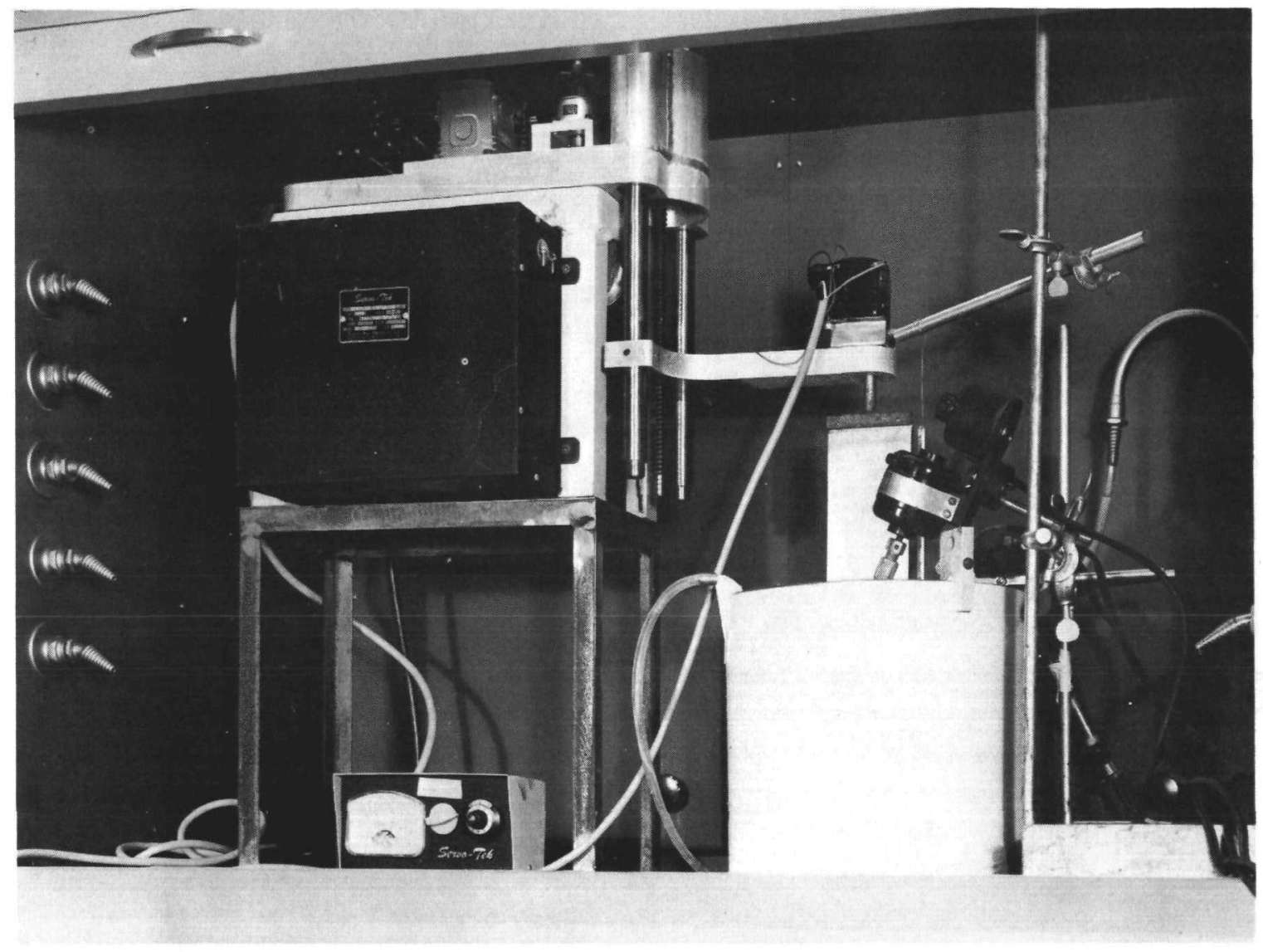

117781

Figure 2. ASSEMBLY WITH THE FIN SPECIMEN IN THE WITHDRAWN POSITION.

\section{TEST PROCEDURE}

The bath consisted of ten volume percent sulfuric acid in demineralized water. The beryllium specimen was submerged to a depth of $71 / 4$ inches, rotated at three revolutions per minute, and withdrawn from the bath at a constant rate. The first specimen was milled prior to the introduction of the cooling coil. Cooling coils were used in the bath for the balance of the tests in order to compensate for the heat of solution of beryllium in sulfuric acid solution and, therefore, maintain a constant bath temperature throughout the run. The effect of the process variables (bath temperature and withdrawal rate) upon beryllium removal by chemical milling is indicated by the data of Table 1. The thickness measurements of the last three of these fin specimens are plotted in Figure 3. As the curves indicate, there was little difference between the fins tapered at 25 and $27^{\circ} \mathrm{C}$, but there was a significant difference obtained from a specimen tapered in the $30^{\circ} \mathrm{C}$ bath. 
Table 1

RESULTS OF CHEMICAL MILLING BERYLLIUM SHEET

\begin{tabular}{cccc}
\hline $\begin{array}{c}\text { Withdrawal } \\
\text { Rate } \\
\text { (in/min) }\end{array}$ & $\begin{array}{c}\text { Bath } \\
\text { Temperature } \\
(0 \mathrm{C})\end{array}$ & $\begin{array}{c}\text { Taper in } \\
\text { Seven Inches } \\
\text { (inch) }\end{array}$ & $\begin{array}{c}\text { Bath } \\
\text { Condition }\end{array}$ \\
\hline 0.086 & $35-55$ & Variable & New \\
0.086 & 30 & 0.048 & $\begin{array}{l}\text { Used and } \\
\text { Replenished }\end{array}$ \\
0.086 & 35 & 0.139 & New \\
0.112 & 25 & 0.073 & New \\
0.112 & 30 & 0.100 & New \\
0.112 & 27 & 0.080 & New \\
\hline
\end{tabular}

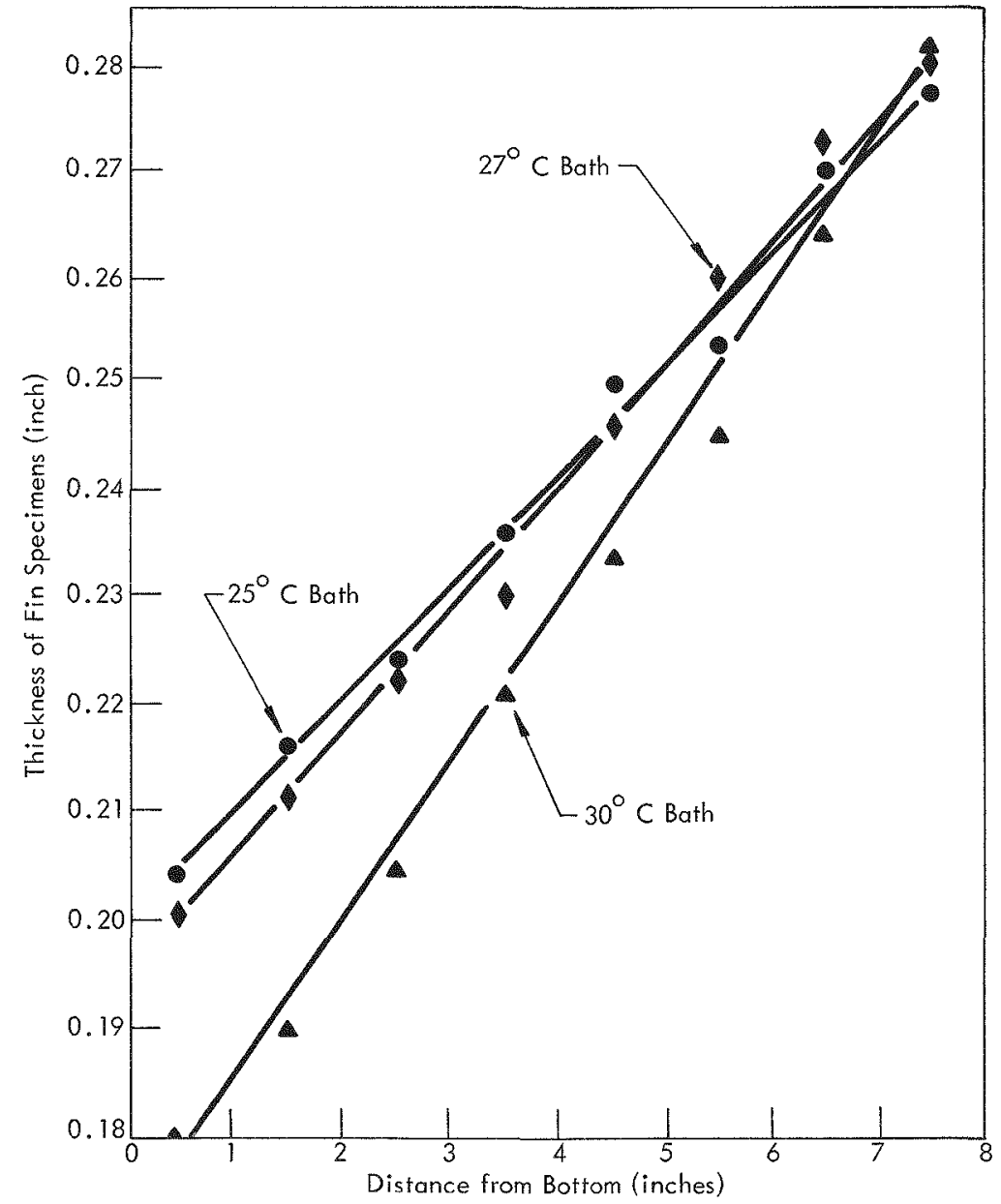

Figure 3. THICKNESS VARIATION OF CHEMICALLY MILLED FINS. 
RESULTS

From this study, the following statements can be made:

1. Of the six fin specimens chemically milled, only one was successfully milled to the desired taper of 0.080 inch over the $71 / 4$-inch length of the specimen. In this run, the withdrawal rate was increased from 0.086 to 0.112 inch per minute to reduce the taper in $71 / 4$ inches to 0.080 inch.

2. The bath temperature was extremely critical and had to be maintained at $270 \mathrm{C}$ to obtain a 0.080 -inch taper.

3. A new solution was required for each fin specimen because chemical milling with a used and replenished bath could not be controlled to produce the desired specimen taper.

4. The taper was not uniform on the specimens after chemical milling due to the variation in thickness of the original hot-rolled beryllium ingot sheet and excessive attack at the rolling defects.

5. The chemically milled surface was not pitted as sometimes occurs in this metal removal process. 


\section{CONCLUSIONS}

Only six chemical-milling tests were conducted on beryllium; consequently, the results cannot be considered conclusive but they do demonstrate that the taper of the beryllium fins can be chemically milled in a sulfuric acid bath within a reasonable length of time. There is some variation in the taper and this maybe objectionable because atolerance of \pm 5 percent on all dimensions along the taper is required. Some of this variation is the result of the warped condition of the sheet, nonuniform thickness of the hot-rolled sheet, and preferential attack at the rolling defects.

For this particular application (tapering beryllium fins) chemical milling is not economical in comparison with conventional machining techniques. 